\title{
Restoring Voices
}

A B S T R A C T

The article discusses the work titled Myśl teatralna doby postyczniowej. Antologia (Theatrical thought of post-January era. Anthology, Opole 2016), selection and elaboration by Sabina Brzozowska and Marek Dybizbański. The unique usefulness of the book can be seen in two ways: firstly, it will be used in university didactics (both theatrical and Polish studies), and secondly, it will create a valuable basis for further historical and theatrical research.

KEYWORD S

Polish drama, Polish theatre, theatrical criticism

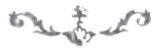

DOI: $10.18318 /$ wiekxix.2017.25

Aneta Mazur

(Uniwersytet Opolski)

\section{MIRON WŚRÓD PRĄDÓW EPOKI}

Rec.: Marta Barańska, Twórczość Aleksandra Michaux (Mirona) wobec prąów ideowych i artystycznych XIX wieku, Wydawnictwo „Poznańskie Studia Polonistyczne”, Poznań 2016, ss. 188.

„Dziś żaden miłośnik dobrej poezji nie sięga już po tomiki Mirona” ${ }^{1}$ Przeszło pół wieku po wydaniu tego surowego sądu chciałoby się powiedzieć: dziś żaden miłośnik Mirona nie sięga już po artykuł, w którym te słowa padły. A jeśli nawet z racji znikomej liczby opracowań dwudziestowiecznych - sięgał do tej pory, to należy mieć nadzieję, że odtąd nie będzie musiał tego czynić, bo zapomniany pisarz doczekał się wreszcie odrębnej monografii. Aleksander Michaux (1839-1895), poeta, tłumacz, publicysta, dziennikarz i nowelista, jako przedmiot zainteresowania historyków literatury miał zdecydowanie mniej szczęścia niż tacy współtowarzysze poetyckiej niedoli, zabłąkani wraz z nim między tryby pozytywistycznej machiny, jak Felicjan Faleński czy Wiktor Gomulicki², nie wspominając już gwiazdorskiego duetu Adama Asnyka i Marii Konopnickiej. Gwiazda jego talentu zaświeciła na krótko w latach sześćdziesiątych i siedemdziesiątych XIX wieku, by zgasnąć $\mathrm{w}$ aurze wstydliwego skandalu nieuleczalnego alkoholizmu i umysłowej degrengolady, ku umiarkowanemu żalowi współczesnych, który z upływem

1 J. Komar, Miron, w: Obraz literatury polskiej XIX i XX wieku, Seria 4: Literatura w okresie realizmu i naturalizmu, red. J. Kulczycka-Saloni, H. Markiewicz, Z. Żabicki, t. 1, Warszawa 1965, s. 273.

2 Wiktor Gomulicki - jak podkreśla autorka recenzowanej monografii - pozostawił jedne z najcenniejszych świadectw o życiu i twórczości Aleksandra Michaux. 
czasu miał się przemienić w obojętność, a nawet pewien rodzaj niechęci potomnych. Jak słusznie pisze autorka monografii, Marta Barańska: „[...] historia literatury [...] «wstydzi się» Mirona, traktuje go z pewnym zażenowaniem, przypominając niekiedy wyłącznie na zasadzie swoistego curiosum literackiego" (s. 185). Ukuta swego czasu metafora „zabijania poetów” (Jan Tomkowski) jest oczywiście efektowną hiperbolą, ale nie sposób oprzeć się wrażeniu, że po zjadliwych komentarzach autorytatywnego na wiele (chyba zbyt wiele) lat Piotra Chmielowskiego - zaliczył on Mirona „do rzędu kwilących bezsilnie ptasząt, na które w dziele pracy społecznej rachować niepodobna" ${ }^{3}$ - właśnie cytowany wyżej rozdział fundamentalnego kompendium Obraz literatury polskiej przypieczętował wyrok skazujący Michaux na uśmiercenie. To ów rozdział czyta się dzisiaj z zażenowaniem, zwłaszcza po podjętych w międzyczasie sporadycznych próbach rehabilitacji „poety przeklętego". Tak negatywnej, wprost pogardliwej oceny nie usprawiedliwiały chyba ani przymus społecznej ideologizacji literatury, ani kryterium poszukiwania oryginalnego artystycznego „chwytu”, jakie obowiązywały w latach sześćdziesiątych minionego wieku; czytelnik odnosi wręcz wrażenie, jakby celem badacza było wykazanie niskiego poziomu rzemiosła poetyckiego Mirona ${ }^{4}$. Nic dziwnego, że autorka monografii prawie nie uwzględnia tej podstawowej bądź co bądź pozycji bibliograficznej w swojej książce.

Dlaczego tak dużo o artykule Jerzego Komara? Bo wnikliwa praca Marty Barańskiej, badaczki reprezentującej środowisko poznańskie, znane z rzetelnej dyscypliny filologicznej, jest nader udanym przykładem zanegowania (by nie rzec: skompromitowania) niefortunnych tez oraz stanowiska poprzednika, a tym samym stanowi swoistą historycznoliteracką rekompensatę. Nie znaczy to, by autorka poddała się nieuniknionej sympatii dla przedmiotu swych badań i zajęła krańcowo przeciwną pozycję obrońcy - główny walor jej rozprawy to właśnie sine ira et studio. Można odnieść wrażenie, że Barańska starannie stroni od wszelkich wyrazistych sądów aksjologicznych; przynajmniej ich liczba jest znikoma5. To dobrze, że twórczość drugorzędnych poetów pozytywizmu doczekała się wreszcie adekwatnych badaczy, pozbawionych kompleksów ideologicznych, wyzbytych

3 P. Chmielowski, Współcześni poeci polscy, Petersburg 1895, s. 345.

4 Przykłady bardziej negatywnych określeń: „niezdecydowanie i eklektyzm”, „dezorganizacja wypowiedzi”, „nieporadności wręcz śmieszne”, „zupełnie przypadkowe zespolenie niezwiązanych artystycznie składników”, język był „elementem, który najtrudniej poddawał się woli pisarza. [...] próby inwencji językowej są zwykle nieudane”, „Mirona współcześnie przeceniano" (J. Komar, dz. cyt., s. 271-272, 268). Orientacja formalistyczna jest ewidentna w stwierdzeniu, że poeci epoki postromantycznej „nie umieli przezwyciężyć w poetyce inercji «chwytów zautomatyzowanych»" (J. Komar, dz. cyt., s. 268).

Do najwyrazistszych należy może końcowy komentarz na temat dorobku poety: „Jego działalność - paradoksalnie, mimo składanych przez kreowany podmiot liryczny deklaracji o skłóceniu ze społeczeństwem - miała jednak charakter zdecydowanie użyteczny. Byłaby to użyteczność [...] rozumiana jako «udział w zbiorowej pracy», przejawiająca się w działalności przekładowej, wydawniczej i popularyzatorskiej" (s. 179). 
pretensji metodologicznych, zorientowanych na to, co najważniejsze - uwolnione od aksjologii poszukiwanie specyfiki poszczególnych przypadków, klasyfikację i opis tego, co tam JEST, a nie tego, czego w nich NIE MA. Zbyt długo bowiem historycy literatury wydawali się kontynuować listę zażaleń Chmielowskiego i Świętochowskiego: że poeci doby niepoetyckiej nie byli drugim Mickiewiczem czy Norwidem; albo, że byli tacy, jacy byli; albo... że w ogóle byli.

Studium Marty Barańskiej składa się z czterech części, zamkniętych krótkim podsumowaniem. Wstęp omawia stan wiedzy biograficznej o tym polskim literacie ciekawego, francuskiego lub belgijskiego pochodzenia, wzbogacając ją o nieznane bądź zapomniane fakty. Dowiadujemy się na przykład nie tylko o legendarnym już alkoholizmie Mirona, ale o podjętych próbach ratunku - terapeutycznych podróżach zagranicznych wraz z rodziną i poszukiwaniu azylu w klasztorze; o opiece, sprawowanej przez poetę nad siostrzeńcem; o istnieniu trojga dzieci Michaux: zmarłej w dzieciństwie córce oraz dwóch synach. Autorka dezawuuje też swoisty mit literacki, utrwalony jeszcze przez Gomulickiego, o „restauracyjno-filisterskim rodowodzie" (s. 13), jaki miał w znaczący sposób determinować postawę warszawskiego „dandysa” i „bajronisty”, syna stołecznego restauratora. Trzy pozostałe, zasadnicze części pracy, zgodnie z zapowiedzią tytułową ukazują twórczość Mirona „wobec prądów ideowych i artystycznych XIX wieku”.

Rozdział pierwszy i najdłuższy, Poeta a świat. W kręgu (post)romantycznej topiki poetyckiej, prezentuje zestaw motywów, tematów i konwencji, zwyczajowo traktowanych jako postromantyczno-epigońskie, a obsługujących problematykę autotematyczną, relacji artysty do rzeczywistości (szkoda, że korespondujący z motywem tytułowym wiersz Świat i poeta nie został omówiony dokładniej, poza wzmianką na s. 68). Przedmiotem analizy staje się między innymi urokliwa topika syren-rusałek (też w wersji femme fatale), melancholii, błazna, szaleństwa czy ptaka (ta ostatnia metafora poety szeroko i ciekawie omówiona - s. 31-35, 53-54). Generacyjne zawieszenie Mirona w epoce przejściowej przesądziło o niejednoznacznej postawie wobec sztuki, podlegającej u niego ambiwalentnej (de)sakralizacji: to życiodajny ideał z jednej strony, destrukcyjna iluzja z drugiej. Stąd też panujący w tej twórczości melanż tonacji, gdzie patosowi i sentymentalizmowi towarzyszą ironia i groteska (ta ostatnia nie zawsze zamierzona, w czym autorka wyjątkowo zgadza się z Jerzym Komarem). „Romantyczne «ja» Mirona nie jest spójne”, konkluduje Barańska, a za przykładową ilustrację niech posłużą dwa cząstkowe wnioski badaczki: „koncepcja cierpiącego, nieszczęśliwego artysty, promowana przez Michaux” - oraz - „postać poety” na miejscu „biblijnego smoka zwodzącego ludzkość i strąconego na ziemię" (s. 83, 60, 76). Autorka kwestionuje przy tym kierowane pod adresem poety oskarżenia o rzekomą bierność czy pasywność wobec zjawisk współczesności, widząc w jego zmaganiach ze światem niejakie połączenie „romantycznej koncepcji twórcy z jej młodopolską kontynuacją” (s. 83).

Rozdział drugi Wobec „czasów niepoetyckich” koncentruje się na utworach, w których Miron zawarł mniej lub bardziej krytyczne diagnozy ówczesnej rzeczy- 
wistości światopoglądowej, cywilizacyjnej i społecznej. Poemat Don Juan (1865) podejmuje Byronowskie szyderstwo wobec świata, przyrównanego przez poetę do "wazy z błota” (s. 94); w jego immoralnym bohaterze widzi autorka portret swoistej banalności zła, właściwej epoce odległej od tragicznego pierwowzoru. Dramat Bez Boga. Fantazja (1870) to rodzaj filozoficznego moralitetu w gotyckiej scenerii, prezentującego szaleństwo demonicznego racjonalizmu i materializmu. Jako że „przestrzeń miejska zdecydowanie dominowała w utworach Mirona” (s. 98), najwięcej uwagi poświęca badaczka jego lirycznym migawkom z życia miasta; podkreśla przy tym ich pionierski charakter, przyćmiony przez późniejsze obrazki Konopnickiej i Gomulickiego, choć to oni właśnie mogli czerpać inspiracje z twórczości Michaux. To chyba najlepsze partie książki Barańskiej, pełne inwencji i ciekawych, szczegółowych spostrzeżeń analitycznych. Za swoisty popis egzegetyczny uznać trzeba prezentację Fotografii brukowych (1869), omówionych z wirtuozerią, wraz z całym szeregiem mini-szkiców kulturowych, wzbogacających konteksty interpretacyjne (m.in. dygresje poświęcone tradycji dziadów proszalnych, specyfice rodzącej się fotografii czy dziewiętnastowiecznej topice danse macabre). Rozwijając uwagi innych badaczy, wskazujących na formalne i tematyczne nowatorstwo wierszy Mirona, poświęconych miastu, Barańska w sposób przekonujący wykazuje, że nie jest to tylko szereg naiwnych, sentymentalnych czy dydaktycznych obrazków z codzienności warszawskiej biedoty - ale także „cykl o przemijaniu i nietrwałym charakterze wartości, takich jak uroda, bogactwo, szczęście rodzinne, [...] o przewrotności losu" (s. 136). I tak na przykład obrazek Biedny stolarz, który dla autora artykułu z Obrazu literatury polskiej był jedynie „jaskrawym przykładem nieumiejętności doboru realiów" ", zostaje finezyjnie odczytany jako przejmujący wariant „tańca śmierci” (s. 133-134). Wypływające z tych utworów sugestie, „że we współczesnej rzeczywistości nie ma miejsca ani dla ubogich, ani dla artystów" (s. 115), oraz sądy potępiające tę rzeczywistość, nie oznaczały jednak u Mirona wiary w możliwość powrotu do przeszłości jako utopii wolnej od praw ekonomii i postępu. Stąd pesymistyczny, melodramatyczny, choć także biedermeierowsko-liryczny charakter jego quasi-werystycznych, „kameralnych” diagnoz.

Trzeci rozdział pod tytułem $W$ świecie sztuki. Poezja jako antykwariat zajmuje się korespondencjami plastycznymi w twórczości poety, omawiając je na wybranych przykładach. Ostatnia część pracy ma charakter wyraźnie autotematyczny: stawiając tezę o eklektyzmie estetycznym i „«kolekcjonowaniu» stylów” (s. 149) jako cechach charakterystycznych dla utworów Michaux, autorka wyostrza tylko orientację, którą przyjęła w całym swoim wywodzie. Podobnie interpretowane tutaj teksty (przeważnie wczesne, $z$ lat sześćdziesiątych) stanowią rodzaj autotematycznych, po części autobiograficznych sygnałów. Należą do nich zwłaszcza prozatorski szkic Antykwariusz (1866) - obraz miłośnika i kolekcjonera przeszłości, którego „życie wśród szczątków” (s. 151), przerwane przez śmierć, pozostaje

J. Komar, dz. cyt., s. 270. 
nieukończonym fragmentem, oraz cztery najbardziej chyba znane i reprezentatywne wiersze Mirona, często przywoływane jako credo poety - sonety dedykowane „popiersiom” Juliusza Słowackiego, Heinricha Heinego, George’a Byrona oraz Alfreda de Musseta. Te ostatnie interesują autorkę wprawdzie głównie jako zabiegi na płaszczyźnie poetyki i obrazowania, podkreśla jednak oksymoroniczność tych lirycznych portretów, koryguje też stereotypowy wizerunek Heinego według niej dla Mirona jest on bardziej sceptykiem niż cynikiem-ironistą (s. 176). Pozostałe, analizowane utwory, wśród nich także przykład ekfrazy, służą wykazaniu ciekawych paralel oraz aluzji malarskich czy estetycznych, do których Michaux wykazywał wyraźne predylekcje (Ballada. Obrazek nie flamandzki; Strącone gniazdko. Do obrazu Szermentowskiego; W katedrze gotyckiej; Fragment. Ze wspomnień egzaltowanego dziecięcia XIX wieku. Szkic kwaczem). Cenny wątek w tej części pracy stanowią nieznane, publicystyczne wypowiedzi Mirona na temat malarstwa. Poeta preferował Jana Matejkę i Aleksandra Gryglewskiego, pejzażystów Jacoba van Ruisdaela i Claude’a Lorraina, a ponadto omawiał obrazy między innymi Wojciecha Gersona, Adama Maleckiego, Henryka Pillatiego, Józefa Simmlera i Józefa Szermentowskiego. Jego gusta estetyczne grawitowały w kierunku idealizującego bądź sentymentalnego (postromantycznego) klasycyzmu. Choć poeta - „jak się zdaje”, zastrzega autorka - „opowiada się przeciwko «flamandyzmowi» i realizmowi" (s. 167), to jednak w swoich utworach prowadzi swoistą grę z tymi konwencjami, co znowu daje badaczce okazję do rozbudowania wywodu o szereg kontekstów i odniesień, tyczących zwłaszcza tradycji malarstwa flamandzkiego (Rembrandt, Gerard Dou, David Teniers i inni).

W sumie kompozycja monografii jest przemyślana, logicznie trafna i przekonująca. A jednak czytelnik odnosi wrażenie pewnej umowności rozkładu materiału w poszczególnych rozdziałach; tak naprawdę nad całością dominuje w sposób absolutny dyskurs intertekstualny, w którym tropienie meandrów topiki ważniejsze jest od rozpoznania ewentualnych „prądów” (wyraźnie wyłaniają się tylko postromantyzm i klasycyzm) czy innych zwartych kontekstów interpretacyjnych - a wiele analizowanych motywów mogłoby się właściwie zamienić miejscami bez zbytniej szkody dla konstrukcji wywodu. Dlatego omówienie zawartości poszczególnych rozdziałów nie oddaje specyfiki pracy Barańskiej. Jest to splątana tkanina międzytekstowych odniesień, konotacji i przyczynków, istny labirynt motywów, obrazów i epizodów, wśród których podróżujemy wraz z autorką, wciągani nieraz w głąb kolejnych dygresji, rozwijających się na podobieństwo kompozycji szkatukkowej, wodzeni swawolnie „na boki”, by po przeglądzie całego szeregu korespondencji i paralel powrócić do punktu wyjścia, to jest do utworu, o którym, bywa, już prawie zdążyliśmy zapomnieć. Praca, której nieco dekostrukcjonistyczna teza prezentuje dorobek Mirona jako eklektyczny zabieg kolekcjonerski, sama jest również takim zabiegiem: kolekcjonuje wybrane wątki i fragmenty twórczości poety, nie troszcząc się zbytnio o spójny, uporządkowany przekaz. Choć miejscami może to nieco irytować, w sumie stanowi jednak fascynujący sposób prowadzenia ba- 
dawczej narracji, zwłaszcza że praca napisana jest potoczystym, klarownym i lekko ozdobnym stylem, przez co przyswaja się ją z przyjemnością. Tradycjonaliści monografii historycznoliterackich mogliby wprawdzie zapytać, dlaczego nie wyłania się tutaj jasny obraz uprawianych przez Mirona rodzajów i gatunków literackich, uporządkowana, chronologiczna i genologiczna synteza jego twórczości. Tylko czy uśmiercony stereotypowymi krytyczno(historyczno)literackimi sądami poeta rzeczywiście tego najbardziej potrzebuje? Zresztą autorka, świadoma potencjalnych zarzutów tego rodzaju, uprzedziła je, podsumowując swoje studium słowami:

Klasyfikacji takiej [dokonywania restrykcyjnych podziałów i uszeregowań] bowiem Michaux się nie poddaje, a zjawiska przypisywane konkretnym fazom polskiego XIX wieku współistnieją w jego utworach i twórczo się przeplatają. Tak widziany poeta jest zarazem spadkobiercą romantyzmu oraz piewcą przeszłości, jak i aktywnym podmiotem kształtującym obraz swojej współczesności, reagującym na to, co aktualne, a także kimś, kto współtworzy tradycję dla kolejnych pokoleń, a więc - ucieleśnieniem ducha stulecia.

$(\text { s. } 187)^{7}$

Ale to nie jest najważniejsze alibi autorki. Istotniejszy wydaje się fakt, iż obrana technika prezentowania poezji Mirona idealnie odpowiada chaotycznej erudycji i tak długo negatywnie ocenianej skłonności poety do parafrazowania czy cytowania, a zatem niejako naturalnej, przyrodzonej jego temperamentowi intertekstualności, o której autorka wielokrotnie wspomina, posługując się także metaforami krytyków: „pajęcza siatka słowa” (s. 26); „zaczarowane kółka”, jakie w poezji Michaux tworzą „motto, cytat, auto-cytat i aluzja” (s. 170); „Dramat niewyrażalności przejawia się tutaj w upodobaniu do cytatu, licznych powtórzeń, aluzji i reminiscencji literackich" (s. 72). Lista nazwisk pisarzy tłumaczonych przez Mirona jest imponująca, jak zwraca uwagę Barańska, ale równie imponująca jest lista odwołań pojawiających się w jego tekstach (żeby wymienić tylko najważniejszych artystów słowa: Homer, Platon, Petrarka, Dante, Shakespeare, Milton, Kochanowski, Gautier, Béranger, Heine, Byron, Musset) - a jeszcze bardziej imponująca, co oczywiście nie zaskakuje, jest sieć kulturowych odniesień, jakie przywołuje i tka swoim wywodem sama autorka ${ }^{8}$. W ten sposób krytykowana szkico-

7 Barańska powołuje się tutaj na kategorię eklektycznej, ambiwalentnej dziewiętnastowieczności, wypracowaną przez badaczy poznańskich (Tomasz Sobieraj, wcześniej też Janusz Maciejewski i Józef Bachórz). Także środowisko poznańskie pracuje w ramach projektu badawczego NPRH nad rozpoznaniem „Poezji na marginesie cywilizacji”. Czekamy zatem na kolejne rehabilitacje „zapomnianych” i „przeklętych” poetów epoki niepoetyckiej.

8 Następujące wyliczenie nie obejmuje całego zestawu: Mickiewicz, Słowacki, Norwid, Zaleski, Pol, Syrokomla, Sztyrmer, Dunin-Borkowski, Wolski, Szymanowski, Lenartowicz, Aspis, Stebelski, Grudziński, Wincenty Stroka, Wołody Skiba (Sabowski), Faleński, Gomulicki, Oppman, Ordon, Asnyk, Konopnicka, Kraszewski, Kaczkowski, Prus, Boccaccio, Machiavelli, Tasso, Goethe, Matthew Lewis, E.T.A. Hoffmann, Longfellow, Walter Scott, Leconte de Lisle, Sully Prudhomme, Hugo, Renan. Wśród interesujących paralel, proponowanych przez Barańską, zabrakło odnotowania - może przeoczonej, a może zbyt oczywistej - przewrotnej aluzji do Mickiewiczowskiego wiersza Do Matki Polki w puencie Fragmentu Mirona 
wość tekstów Mirona, ich nieskoordynowana, dygresyjna i kapryśna kompozycja, skutkująca nieraz wspomnianą nieczytelnością przekazu - nie wiadomo, na ile świadomą, na ile zdradzającą nieudolność autora - niespodziewanie zyskuje modernistyczny walor. Przyznać trzeba, że praca Marty Barańskiej to świetny przepis na podważenie fatalnej etykietki epigonizmu, a także takich tradycyjnych zarzutów krytyki, jak nieszczerość, sztuczność czy pretensjonalność. Kto wie, czy nie jest to również najlepszy sposób na pobudzenie apetytu na lekturę wierszy Aleksandra Michaux: ukazanie niektórych, najciekawszych konturów i fragmentów, aby kazać domyślać się reszty. A może - by zakończyć nieco przewrotnie aby oszczędzić czytelnikowi widoku reszty?

Na zakończenie, w ramach obowiązków Zoila, parę krytycznych uwag szczegółowych. Wnioskować należy, że autorka dokonała solidnej i szerokiej kwerendy czasopism, ale jeśli ogólny zarys uprawianych przez Mirona form wypowiedzi można na podstawie książki zrekonstruować - sonety, pieśni, ballady, poematy, obrazki prozą i wierszem, „fotografie”, „fragmenty” (piętno upodobań postromantycznych), dramat (według świadka epoki niezrealizowanym marzeniem poety był „piękny, szekspirowski dramiec” - s. 86) - to jednak trudno przeboleć brak dokładniejszych informacji o krótkich formach prozatorskich, które pisarz również uprawiał, a z których omówiona zostaje tylko jedna (mimo iż zarówno Nowy Korbut, jak i artykuł Komara wymieniają nowelę Pojedynek oraz „inne obrazki prozą rozsiane po czasopismach" "). Poważną formalną wadą pracy jest brak bibliografii, która, zwłaszcza w przyjętej strategii kapryśnego nieco dyskursu, pomogłaby w orientacji zarówno w dorobku Mirona, jak wśród poświęconych mu wypowiedzi. Podobną usterką, nie tyle pracy, ile już książki, jest nieobecność indeksu, który ów brak po części rekompensowałby, nie wspominając już o tym, że stanowiłby pomoc dla czytelnika, skazanego na żmudne poszukiwanie tytułów, nazwisk bądź wzmianek poprzez cierpliwe kartkowanie książki i studiowanie poszczególnych przypisów (dodatkowym utrudnieniem jest niepowtarzanie pełnych adresów bibliograficznych w każdym rozdziale z osobna). Literówki w tytułach wierszy (s. 50 - In excelsior zamiast In excelsis; s. 170 - Stracone gniazdo zamiast Stracone gniazdo) są nie tylko usterkami formalnymi, lecz mimowolnymi omyłkami merytorycznymi. Na stronach 177-178 dezorientujące jest wprowadzenie pseudonimu Fantazy bez wyjaśnienia. I ostatnia uwaga formalna: brak graficznego separatora między polem tekstu i przypisów nie jest z punktu widzenia czytelnika rozwiązaniem najszczęśliwszym.

(1871): „Matko! Jeśli masz dziecię, / Które mówi rymami, / Wskaż mu ludzi na świecie / Z łez pełnymi oczami. / Niech fabrykuje mydło, / Handluje lub rżnie bydło” (s. 114).

9 J. Komar, dz. cyt., s. 273. Barańska zadawala się formułą: „[...] sięgał również po krótkie formy prozatorskie" (s. 86). 
Aneta Mazur (University of Opole)

e-mail: amazur@uni.opole.pl

\section{Miron among the Trends of the Epoch}

\section{A B S T R A C T}

The book by Marta Barańska, Twórczość Aleksandra Michaux (Mirona) wobec pradów ideowych i artystycznych XIX wieku (The work of Aleksander Michaux (Miron) against the ideological and artistic trends of the nineteenth century, Poznan 2016), is the first monograph of the "cursed poet" of the Positivist era, usually labeled a post-epigenetic epigone. The author revives the view of this work, presenting various lesser-known pieces by Miron (ballads, poems, dramas, prose sketches, publicistic texts) and embedding them in a wide intertextual space. The achivements of this second-grade, long-neglected poet acquire the value of modernity, seen as a collection of motifs, topos and themes, referring to many cultural or artistic archetypes.

KEYWORDS

Aleksander Michaux (Miron), intertextuality, Polish poetry, postromanticism

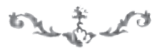

DoI: $10.18318 /$ wiekxix.2017.26

Anna Pekaniec

(Uniwersytet Jagielloński)

\section{EFEKTYWNOŚĆ MIMIKRY}

Rec.: Mateusz Skucha, Niesytość pragnienia. W kręu młodopolskiej liryki kobiet, Wydawnictwo Uniwersytetu Jagiellońskiego, Kraków 2016, ss. 278.

Książka Mateusza Skuchy jest zbiorem błyskotliwych szkiców poświęconych poetkom młodopolskim (zrobiono kilka wyjątków dla poetów, np. Leopolda Staffa czy Edwarda Słońskiego), dzięki którym zostaje wyraźniej niż dotychczas nakreślona mapa młodopolskiej liryki z żeńską sygnaturą ${ }^{1}$. W nocie na okładce Marian Stala zaznaczył:

Książka Mateusza Skuchy konfrontuje historycznoliterackie widzenie twórczości młodopolskich poetek z lekturą inspirowaną przez krytykę feministyczną, genderową i queerową. Dzięki temu zabiegowi zostaje wzbogacony obraz prądów literackich epoki oraz dominujących w niej poetyk i tematów. Zarazem zaś młodopolska poezja kobiet pojawia się jako kontynuacja wcześniejszej i prefiguracja późniejszej walki o odzyskanie przez poetki własnego głosu.

Metafora odzyskiwania głosu to jeden ze stałych toposów krytyki feministycz-

1 Nb. książka stanowi kolejny interesujący element coraz liczniejszej grupy publikacji poświęconych poezji pisanej przez kobiety - zob. np.: A. Legeżyńska, Od kochanki do psalmistki... Sylwetki, tematy i konwencje liryki kobiecej, Poznań 2009; A. Zawiszewska, Między Młoda Polska, Skamandrem i Awangardą. Kobiety piszace wiersze w dwudziestoleciu międzywojennym, Szczecin 2014; J. Grądziel-Wójcik, Przymiarki do istnienia. Wątki i tematy poezji kobiet XX i XXI wieku, Poznań 2016. 